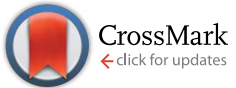

Cite this: RSC Adv., 2016, 6, 108093

Received 25th August 2016

Accepted 1st November 2016

DOI: $10.1039 / c 6 r a 21391 j$

www.rsc.org/advances

\section{Selective aliphatic/aromatic organogelation controlled by the side chain of serine amphiphiles $\uparrow$}

\author{
Jessica Ramos, ${ }^{\mathrm{a}}$ Santiago Arufe, ${ }^{\mathrm{b}}$ Róisín O'Flaherty, $\dot{\dagger}^{\mathrm{a}}$ Denise Rooney, ${ }^{\mathrm{a}}$ \\ Ramon Moreira ${ }^{b}$ and Trinidad Velasco-Torrijos ${ }^{\star a}$
}

The influence of two structural features of $\mathrm{N}$-Fmoc-L-serine lipoamino acids on organogel formation were investigated. These were (i) the nature of the group on the serine side chain (hydroxyl compared to $O$-tertbutyl) and (ii) the length of the aliphatic chain (C-14 compared to C-18). O-tert-Butylated derivatives preferentially gelled saturated hydrocarbon solvents, while compounds with the hydroxyl group in the side chain promoted the highly unusual gelation of solely aromatic solvents. Extension of the chain length of the lipoamino acid (from C-14 to C-18) decreased the selectivity observed for the shorter chain homologues. Spectroscopic analyses of these systems indicated that $\mathrm{H}$-bonds, aromatic $\pi-\pi$ stacking and van der Waals interactions are involved in the gelation processes. Rheological characterization of the gels revealed the aromatic solvent gels to be more stable than their aliphatic counterparts. Scanning Electron Microscopy (SEM) imaging of the xerogels showed that the structure of gels formed in aromatic solvents differs significantly from those formed in aliphatic ones. The different self-assembly modes of the gelator molecules could be induced by steric effects which depend on the functional groups on the side chain. The organogels obtained were thermoresponsive, moldable and capable of self-healing. In addition, the lipoamino acids studied were phase selective gelators in biphasic mixtures of water/organic solvent and efficiently removed water soluble polluting dye rhodamine B from the aqueous phase.

\section{Introduction}

Supramolecular organogels, formed through the self-assembly of small molecules into structured three-dimensional networks, are versatile "smart materials"1,2 which are finding numerous applications in fields as diverse as sensor development, ${ }^{3}$ optoelectronics, ${ }^{4}$ waste management, ${ }^{5,6}$ drug delivery and tissue engineering, ${ }^{7}$ to name but a few. The properties of these systems and their ability to respond to external stimuli strongly depend on the structural features of the molecular species that will trigger the assembly process. ${ }^{8-11}$ The growing interest in this field has prompted research on the methods to predict if a molecule will behave as a low molecular weight gelator (LMWG) and on which solvents it may do so. ${ }^{12}$ In order to rationalize gelling abilities, one needs to take into account not only intermolecular gelator-gelator interactions, but also

\footnotetext{
${ }^{a}$ Department of Chemistry, Maynooth University, Maynooth, Co. Kildare, Ireland. E-mail: trinidad.velascotorrijos@nuim.ie

${ }^{b}$ Department of Chemical Engineering, Universidade de Santiago de Compostela, Rua Lope Gomez de Marzoa s/n, Santiago de Compostela, ES-15782, Spain

$\dagger$ Electronic supplementary information (ESI) available. See DOI: 10.1039/c6ra21391j

\$ Current affiliation: NIBRT Glycoscience Group, National Institute for Bioprocessing Research and Training, Fosters Avenue, Mount Merrion, Blackrock, Dublin 4, Ireland.
}

gelator-solvent interactions. In this regard, solvent polarity, solubility parameters and structural relationships have been investigated. ${ }^{\mathbf{1 3 - 2 0}}$ These studies highlight the impact that subtle structural modifications can have in gelation efficacy. ${ }^{21-23}$ Despite these efforts and the recent advances in the understanding of kinetic and thermodynamic aspects of the selfassembly process ${ }^{24,25}$ it is not yet possible to formulate a model for the design of functional molecular gels. Further empirical evidence of molecular features in LMWGs that lead to selective solvent gelation should therefore contribute to this aim.

Peptides are considered privileged scaffolds for the design of LMWGs since the amide backbone provides both the functionality and structural arrangement for the formation of $\mathrm{H}$ bonds. ${ }^{26}$ Differences in the chemical nature of the side chains can tune the solubility and the additional interactions driving the self-assembly process that may eventually lead to the formation of gels. 9-Fluorenylmethyloxycarbonyl (Fmoc) peptide-based derivatives are good candidates for LMWGs as the fluorenyl group provides the aromatic surfaces required for intermolecular $\pi-\pi$ stacking interactions. ${ }^{27-29} N$-Fmoc peptide gelators have been extensively studied for their abilities to form hydrogels ${ }^{30}$ but there are less examples of their application as organogelators. ${ }^{31,32}$ Some of these describe $N$-Fmoc lipoamino acids behaving as LMWGs in certain organic solvents. ${ }^{33-35}$ 
The manipulation of the side chain functionality can alter the solubility and/or the self-assembly mode of peptide LMWGs. The side chain of L-serine can be easily modified by protecting group chemistry to feature either an $O$-tert-butyl ether or a free hydroxyl group. These transformations can act as a "switch" to access compounds which are structurally similar, but may have very different gelling properties.

This study investigates how structural features such as (i) the nature of the functional group in the side chain and (ii) the length of the hydrocarbon chain of $N$-Fmoc-L-serine lipoamino acids 1-4 affects their ability to form gels. In addition, the lipoamino acids were tested as phase selective gelators of organic solvents in biphasic aqueous mixtures. These systems are gaining increasing attention for environmental applications in water purification. ${ }^{36}$ Thus, we have studied the removal of aromatic pollutants from water by treatment with these LMWGs.
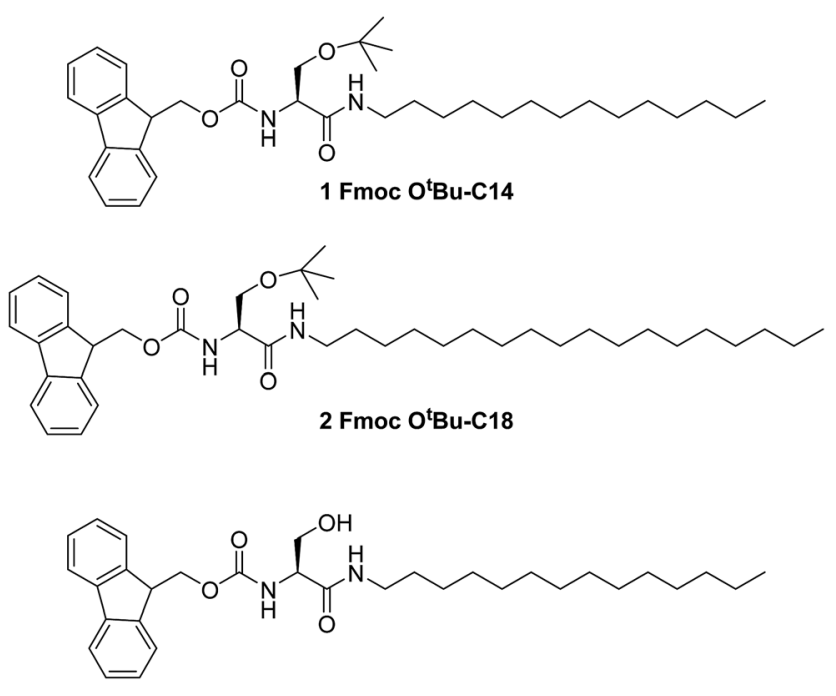

3 Fmoc OH-C14

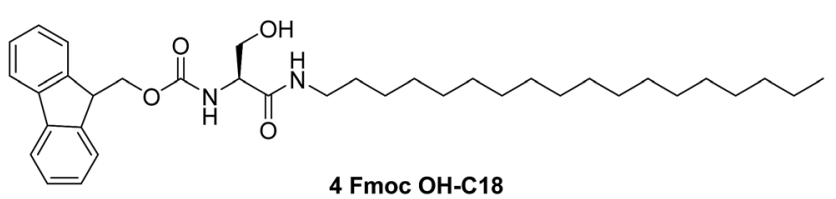

\section{Results and discussion}

\subsection{Synthesis}

The lipoamino acids 1-4 were readily prepared as shown in Scheme 1. Commercially available $\mathrm{N}$-Fmoc-O-tert-butyl-L-serine 5 was reacted with either 1-tetradecylamine or 1-octadecylamine

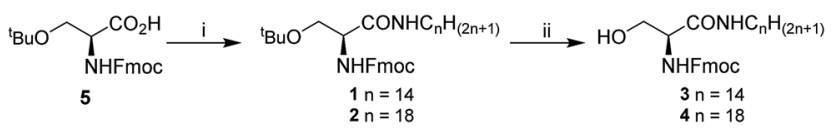

Scheme 1 Synthesis of lipoamino acids 1-4; reagents and conditions: (i) $\mathrm{DIC}, \mathrm{CH}_{2} \mathrm{Cl}_{2}, \mathrm{C}_{14} \mathrm{H}_{29} \mathrm{NH}_{2}(1,95 \%)$ or $\mathrm{C}_{18} \mathrm{H}_{37} \mathrm{NH}_{2}$ (2, 88\%); (ii) TFA, $\mathrm{CH}_{2} \mathrm{Cl}_{2}(3,85 \%)$ or $(4,51 \%)$. using diisopropylcarbodiimide (DIC) as the coupling reagent to give compounds 1 or 2 , respectively. The removal of the side chain tert-butyl ether protecting group was accomplished by treatment with trifluoroacetic acid (TFA) in dichloromethane, yielding the corresponding compounds 3 and 4 .

\subsection{Gelation ability}

The ability of 1-4 to induce the formation of supramolecular gels was then screened in a range of organic solvents of different polarities and structural characteristics (Table 1). Compounds 1-4 were able to form organogels both by sonication and by thermal treatment. The formation of the gel was confirmed by the "inverted tube" test (Fig. S1-ESI $\dagger$ ). It was found that the C-14 lipoamino acid $\mathbf{1}$, with the side chain protected as a tert-butyl ether, showed a preference to form transparent gels with low polarity aliphatic hydrocarbon solvents, with critical gel concentrations (CGC) generally in the "supergelator" range (CGC $<1 \%) .{ }^{37}$ The increase in hydrophobicity imparted by the $\mathrm{C}-18$ hydrocarbon tail in 2 resulted in a reduction in its ability to gel low polarity solvents. Compound 2 was only able to form gels in hexane and heptane but with higher CGCs than its C-14 analogue.

On the other hand, compound 3, featuring the free hydroxyl group on the side chain, behaved as a selective gelator of aromatic solvents, such as benzene, toluene and xylene. 3 was also able to gel commercial petrol, which contained a mixture of aromatic and saturated hydrocarbons. The chain extension in the $\mathrm{C}-18$ hydroxyl derivative 4 resulted in this case in a retention of the ability to gel aromatic solvents (or even an improvement, considering the remarkable CGC of $0.2 \%$ for the formation of xylene gels). However, the ability to selectively induce aromatic over aliphatic solvent gelation was lost, as $\mathbf{4}$ also gelled heptane and cyclohexane. This situation is common to the vast majority of organogelators described in the literature, which are incapable of discriminating the gelation of low polarity solvents.

There has been some interesting reports of selective gelation of specific solvents by LMWG based on saccharides, ${ }^{38}$ bile acids $^{39}$ dendrimers ${ }^{40}$ and hydrazide derivatives. ${ }^{41} \mathrm{~N}$-tert-Butoxycarbonyl ( $N$-Boc) protection/deprotection of amines in peptide gelators has been reported to promote the formation of organoor hydrogels, respectively. ${ }^{42}$ The work reported herein represents the first example in which selective hydrocarbon gelation can be achieved depending on the nature of the functional groups (hydroxyl or tert-butyl ether) present in the gelators side chain. The subtle solubility differences between the C-14 derivatives $\mathbf{1}$ and $\mathbf{3}$ may account for the observed distinction in gelation abilities. The elongation of the hydrocarbon chain in the C-18 derivative 2 and 4 increases their solubility and consequently overrides the side chain effect.

None of the compounds 1-4 formed transparent gels in the higher polarity solvents: 1 and 3 remained in solution, while the increase in the chain length in the $\mathrm{C}-18$ derivatives prompted them to self-associate and form aggregates (2) or opaque gels (4) in ethanol and acetonitrile. These observations correlate well with the reported consequences of alkyl chain extension in organogelators: increasing the lipophilicity of a molecule 
Table 1 Gelation abilities of lipoamino acids 1-4 in different solvents: physical appearance ${ }^{a}$, CGC $(\text { Critical Gelation Concentration, w/v\% })^{b}$ and gel-sol transition temperature $T_{\mathrm{gs}}\left({ }^{\circ} \mathrm{C}\right)^{c}$ at the specified $\mathrm{CGC}$ are indicated

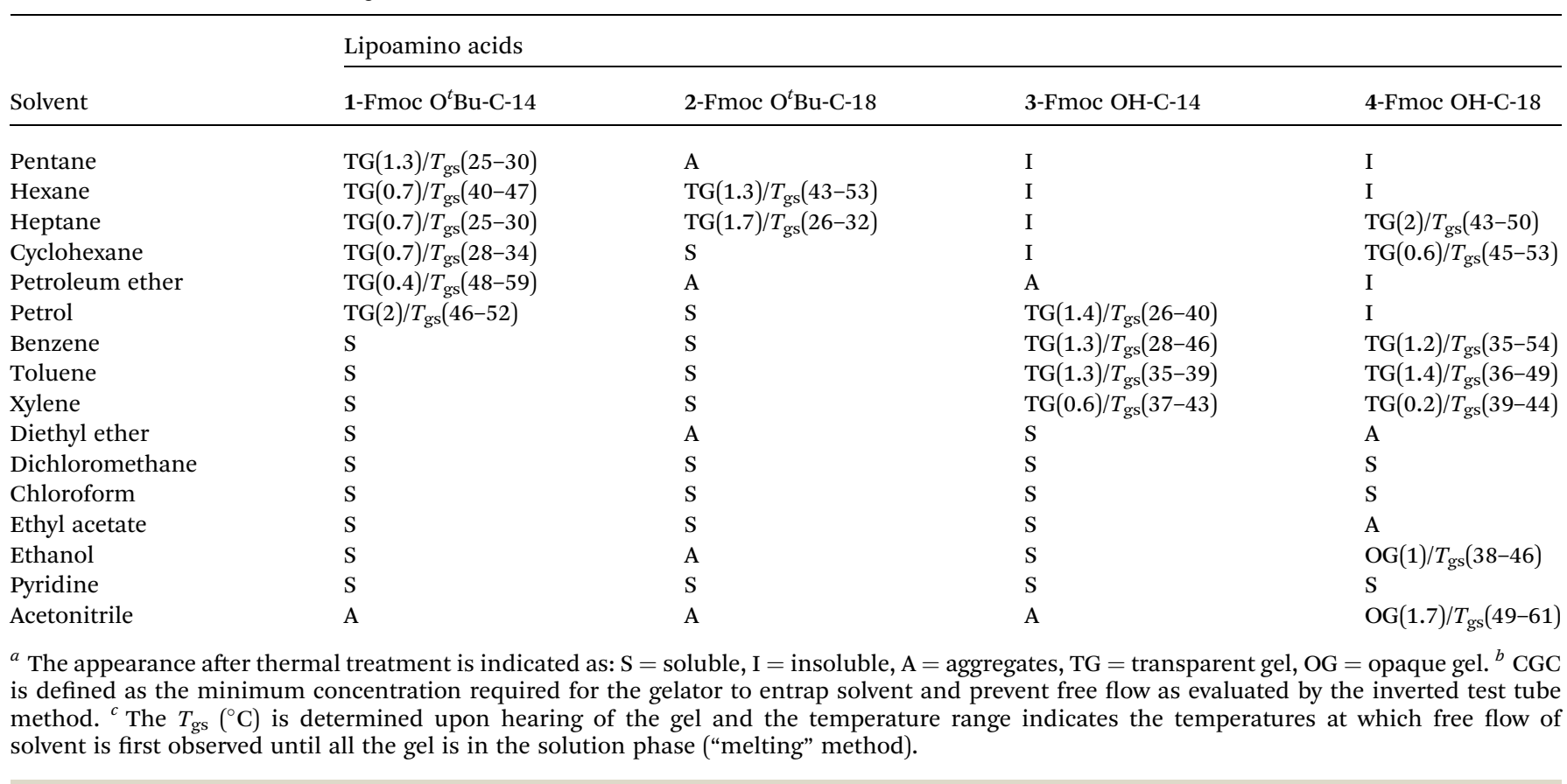

increases its tendency to self-assemble in polar liquids, provided that sufficient solubility is maintained. ${ }^{15}$

\subsection{Rheological evaluation}

The rheological characterization of the organogels formed by 14 in various solvents was carried out. The strain sweep tests allowed the determination of critical strain $\left(\gamma_{c}\right)$ of the samples (Table 2). The $\gamma_{c}$ varied in a narrow interval from 0.23 (3 in toluene) to 0.36 ( 4 in toluene) for all assayed gels, as consequence, a strain of $0.1 \%$ (inside the LVER) was used to determine the mechanical spectra of all gels.

Mechanical spectra of the gels were carried out after 24, 48, 76, 96 and $120 \mathrm{~h}$ of gel formulation in order to evaluate the rheological stability of their structure. Fig. S2-ESI† shows the evolution over time of the mechanical spectra for the gel of 3 in toluene. The viscoelastic modules $\left(G^{\prime}\right.$ and $\left.G^{\prime \prime}\right)$ significantly increased with time until $96 \mathrm{~h}$. At longer times $(120 \mathrm{~h})$, the moduli values remained constant, indicating that a stable structure of gel was achieved. This fact can be also clearly observed analysing the decrease of $\tan \delta$ from 0.34 at $24 \mathrm{~h}$ to

Table 2 Critical strain $\left(\gamma_{c}\right)$ determination of the organogels formed by $1-4$ in different solvents

\begin{tabular}{lll}
\hline Lipoamino acid & Solvent & $\begin{array}{l}\text { Critical strain } \\
\left(\gamma_{\mathrm{c}}\right)\end{array}$ \\
\hline 1-Fmoc O ${ }^{t} \mathrm{Bu}-\mathrm{C}-14$ & Cyclohexane & 0.27 \\
1-Fmoc O ${ }^{t} \mathrm{Bu}-\mathrm{C}-14$ & Hexane & 0.27 \\
2-Fmoc O ${ }^{t} \mathrm{Bu}-\mathrm{C}-18$ & Hexane & 0.35 \\
3-Fmoc OH-C-14 & Toluene & 0.23 \\
4-Fmoc OH-C-18 & Toluene & 0.36
\end{tabular}

0.13 at $96-120 \mathrm{~h}$ (at $1 \mathrm{rad} \mathrm{s}^{-1}$ of angular frequency) that confirms the increase of dominant elastic (i.e. gel) character of the material over time. Similar behavior was observed in the case of the gel in toluene of the C-18 compound 4 . The gels formed in hexane and cyclohexane for the O-tert-butylated compounds 1 and 2 reached the stable state sooner, after $24 \mathrm{~h}$ of gel formulation.

Mechanical spectra of the gels of 3 and 4 (in toluene at $25^{\circ} \mathrm{C}$, at $96 \mathrm{~h}$ after formulation), and of $\mathbf{1}$ and $\mathbf{2}$ (in hexane and cyclohexane at $5{ }^{\circ} \mathrm{C}$, at $24 \mathrm{~h}$ after their formulation) are shown in Fig. 1. All studied gels showed $G^{\prime}>G^{\prime \prime}$ throughout the angular frequency studied range with low values of $\tan \delta$, indicating that

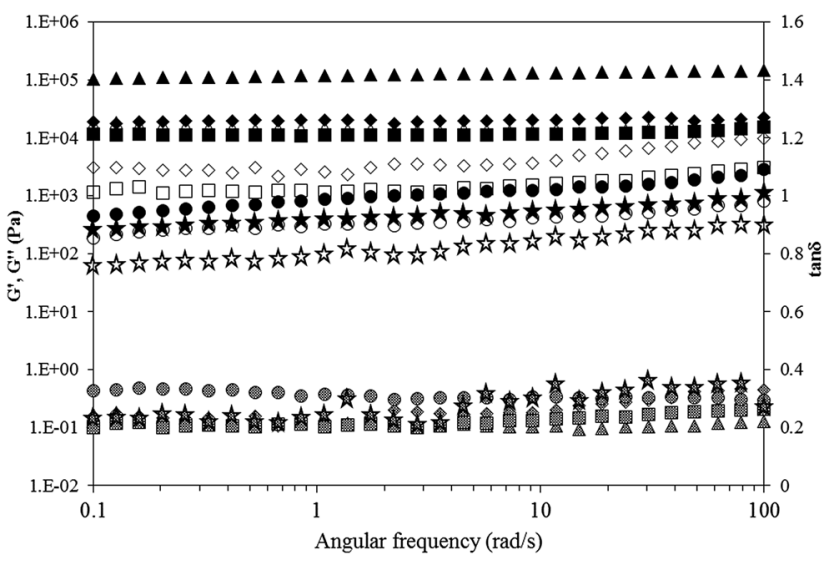

Fig. 1 Frequency sweep at $25^{\circ} \mathrm{C}$ at a strain of $0.1 \%$ for 3 ( $\bullet$, toluene, $1.3 \mathrm{w} / \mathrm{v} \%)$ and $4(\boldsymbol{\Lambda}$, toluene, $1.4 \mathrm{w} / \mathrm{v} \%)$ at $96 \mathrm{~h}$ and at $5{ }^{\circ} \mathrm{C}$ for $1(\bullet$, hexane, $0.7 \mathrm{w} / \mathrm{v} \%) 2(\boldsymbol{\square}$, hexane, $1.3 \mathrm{w} / \mathrm{v} \%$ ) and 1 ( $\star$, cyclohexane, 0.7 $\mathrm{w} / \mathrm{v} \%$ ) at $24 \mathrm{~h}$ ( $G^{\prime}$ (filled markers), $G^{\prime \prime}$ (empty markers) and $\tan \delta$ (dot filled markers). $G^{\prime}$ (storage modulus). $G^{\prime \prime}$ (loss modulus). $\tan \delta=G^{\prime \prime} / G^{\prime}$ ). 
the elastic nature of sample prevailed over the viscous one, such as a typical behavior of a gel structure. The gels in toluene of compounds 3 and $\mathbf{4}$, as well as the hexane gel of compound 2 showed the highest values of both rheological moduli, indicating that they are stronger gels than those formed by the compound 1 in either hexane or cyclohexane.

The toluene gel formed by the C-18 compound 4 presented higher values of $G^{\prime}$ and $G^{\prime \prime}$ and higher elastic character (lower values of $\tan \delta$ ) than the corresponding gel formed by the C-14 compound 3. In both samples, $G^{\prime}$ was invariant with the angular frequency (1.7-2.5 $\times 10^{4} \mathrm{~Pa}$, for gel of 3, 10.4-14.4 $\times 10^{4} \mathrm{~Pa}$ for gel of 4). These values are higher than those reported by other authors for gels of similar nature ${ }^{\mathbf{4 3 , 4 4}}$ and they can be considered strong gels. The extension of the alkyl chain length in the gelators induce different behaviors in these systems: in the toluene gel formed by the C-14 compound 3, $G^{\prime \prime}$ increased appreciably with increasing angular frequency, while in the toluene gel formed by C-18 compound 4 it is almost constant. This fact is easily observable through the increase of $\tan \delta$ at high angular frequencies in the toluene gel of 3 . This result could be related to the promotion of mobility of the gel structure (higher viscous component) in this organogel while for that formed by the longer chain gelator $\mathbf{4}$ the response is almost stationary.

The hexane gels showed lower values of viscoelastic parameters than those discussed earlier, which indicates they are weaker gels. The gels formed with the longest carbon chain compound 2 presented higher values of $G^{\prime}$ and $G^{\prime \prime}$ and lower values of $\tan \delta$. $G^{\prime \prime}$ of both samples depended on angular frequency in the same manner as observed earlier (the gel of the C-14 compound 1 promoted mobility). On the other hand, $G^{\prime}$ showed two different behaviors: the hexane gel formed by the $\mathrm{C}$ 18 compound 2 was almost constant ( 12 to $15 \times 10^{4} \mathrm{~Pa}$ ) while in the gel of the $\mathrm{C}-14$ compound 1 it increased (one decade from 0.3 to $2.8 \times 10^{3} \mathrm{~Pa}$ ) with angular frequency.

The use of different solvents (hexane or cyclohexane) to obtain gels with the same organogelator 1 showed that the rheological response depends on the solvent employed. In fact, at low angular frequencies, both moduli values are closer and viscous character is relevant due to the weak gel formed (lower values of $G^{\prime}$ (271 to $1180 \mathrm{~Pa}$ ) and $G^{\prime \prime}(62.8$ to $320 \mathrm{~Pa})$ ) with the elastic component more predominant at low angular frequency (low values of $\tan \delta$ ), but the viscous character increased appreciably at high angular frequencies in similar manner than the trend described for the toluene gel of $\mathbf{3}$.

\subsection{Thermal analysis. gel-sol transition temperature $\left(T_{\mathrm{gs}}\right)$ and differential scanning calorimetry (DSC)}

The formation of the organogels was found to be thermoreversible. The heating/cooling cycle could be repeated several times without any apparent degradation of the sample or loss of integrity of the gels formed. The gel-sol transition temperatures $\left(T_{\mathrm{gs}}\right)$ are shown in Table 1 and were measured by the "melting" method (described in Table 1, footnote). The extension in the alkyl chain length resulted in a slight increase of the corresponding $T_{\text {gs. }}$. The thermoreversibility of the systems could also be confirmed by DSC measurements (Fig. S3-ESI $\dagger$ ). The DSC analysis of the gel formed by 3 in toluene was carried out $96 \mathrm{~h}$ after formulation to ensure that gel formation was completed. The thermogram (Fig. 2) showed an endotherm at $38.31 \pm$ $2.0{ }^{\circ} \mathrm{C}$ in the first heating cycle corresponding to the gel-sol transition. This correlated well with the $T_{\mathrm{gs}}\left(35-39^{\circ} \mathrm{C}\right)$ determined by the "melting" method. On cooling it shows a sol-gel transition exotherm at $16.08 \pm 0.1{ }^{\circ} \mathrm{C}$ indicating the thermoreversible nature of the gel. ${ }^{\mathbf{4 4 , 4 5}}$ The difference in the heating and cooling peak temperatures indicates a hysteresis characterizing a first order nature in the gelation process. This type of behavior has been reported for other organogelators. ${ }^{46}$ In addition, the transition peaks are better defined in the cooling curve (sol-togel) rather than in the heating curves (gel-to-sol). This is consistent with the simultaneous occurrence of different selfassembly processes, which are characteristic of the gelation process. $^{47}$

The enthalpies associated with the transitions were calculated from the DSC data. It is important to note that the enthalpy of fusion was $1.58 \pm 0.05 \mathrm{~J} \mathrm{~g}^{-1}$ whereas the enthalpy of formation was $0.14 \pm 0.01 \mathrm{~J} \mathrm{~g}^{-1}$. This apparent disparity can be explained by the rheological analysis that showed the need of $96 \mathrm{~h}$ to complete gel formation. The DSC measurements only probe the initial assembly of the gelator molecules into twodimensional (2D) structures, which subsequently organize into three-dimensional (3D) networks that can entrap the solvent. ${ }^{48-51}$

\subsection{Morphological studies}

The morphology of the xerogels of compounds 1-4 was investigated using Scanning Electron Microscopy (SEM) imaging (Fig. S4-ESI $\dagger$ ). The xerogels were formed from the corresponding organogels in different solvents using the drop-cast method. ${ }^{52}$ The presence of densely packed fibrous structures, which appear as grooves on the surface of the xerogels, can be observed for all the xerogels; the fibers dimension and aggregation patterns seem to vary depending on the nature of the

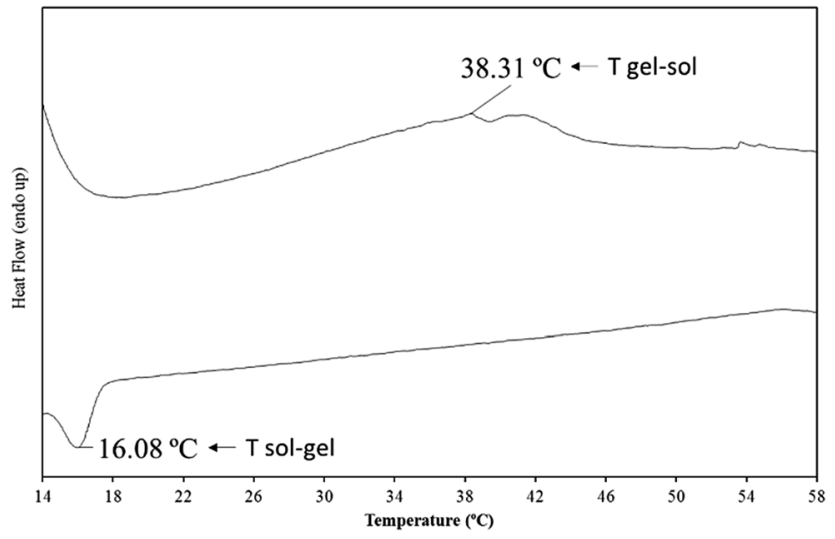

Fig. 2 Differential scanning calorimetry (DSC) thermograms: heating (upper trace) and cooling (lower trace) scans of a gel formed by compound 3 in toluene (1.3 w/v\%); heating and cooling rate $2{ }^{\circ} \mathrm{C}$ $\min ^{-1}$. 
solvent and the organogelator. The images reveal striking differences in the morphologies of the self-assembled fibrillar networks (SAFINs) for the hexane xerogels formed from the $O$ tert-butylated compounds 1 and $\mathbf{2}$ and the toluene xerogels from the hydroxyl derivatives 3 and $\mathbf{4}$. The images for the hexane xerogels from 1 and 2 present ridge-like structures (Fig. 3a and b), likely caused by the aggregation of densely packed fine fibrils. Similar morphologies were observed for the xerogels of $\mathbf{1}$ in aliphatic solvents such as pentane, cyclohexane and heptane (Fig. S4-ESI $\dagger$ ). On contrast, the presence of well-defined fibrous structures or "microbelts", ${ }^{34}$ with diameters averaging $2 \mu \mathrm{m}$, can be clearly observed in the images of the toluene xerogels from 3 and 4 (Fig. 3c and d). The fibers appear to twist, which could be an indication of a helical structure.

It is noteworthy that the lengthening of the alkyl chain does not seem to impart significant differences in the morphology of the xerogels. This suggests that the nature of the functional group in the serine side chain is a structural feature critical to direct the assembly of gelator molecules, which in turn determines the morphology of the subsequently formed xerogels.

\subsection{Spectroscopic analysis}

Spectroscopic analysis was performed in order to study the molecular interactions leading to the self-assembly of the lipoamino acids in different solvents. ${ }^{1} \mathrm{H}$-NMR spectra of $\mathrm{O}$-tertbutylated 1 in $\left(D_{12}\right)$-cyclohexane and of the hydroxyl derivative 3 in $\left(D_{8}\right)$-toluene were recorded at increasing concentrations (Fig. 4). In both cases, a downfield shift for the resonances corresponding to the amide and carbamate $\mathrm{NH}$ protons was observed (Table 3). These values are consistent with the formation of intermolecular $\mathrm{H}$-bonding in organogels. ${ }^{53}$ The comparable increments in chemical shifts $(\Delta \delta)$ upon changes in concentration observed in the $\mathrm{NH}$ signals for both amide and carbamate protons suggest that both groups are similarly a)

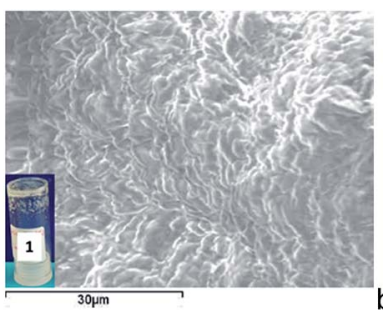

b)

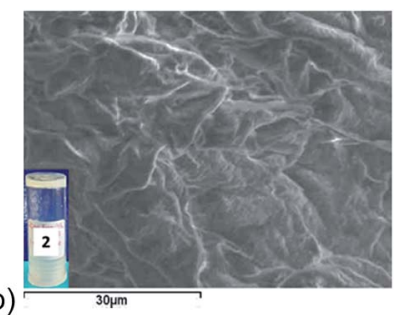

c)
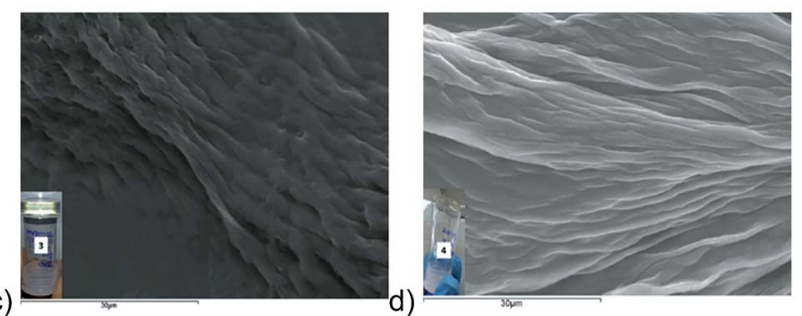

Fig. 3 SEM images of xerogels from lipoamino acids 1-4 formed by the drop-cast method: (a) 1 from hexane at $0.7 \mathrm{w} / \mathrm{v} \%$; (b) 2 from hexane at $1.3 \mathrm{w} / \mathrm{v} \%$; (c) 3 from toluene at $1.3 \mathrm{w} / \mathrm{v} \%$; (d) 4 from toluene at $1.4 \mathrm{w} / \mathrm{v} \%$.

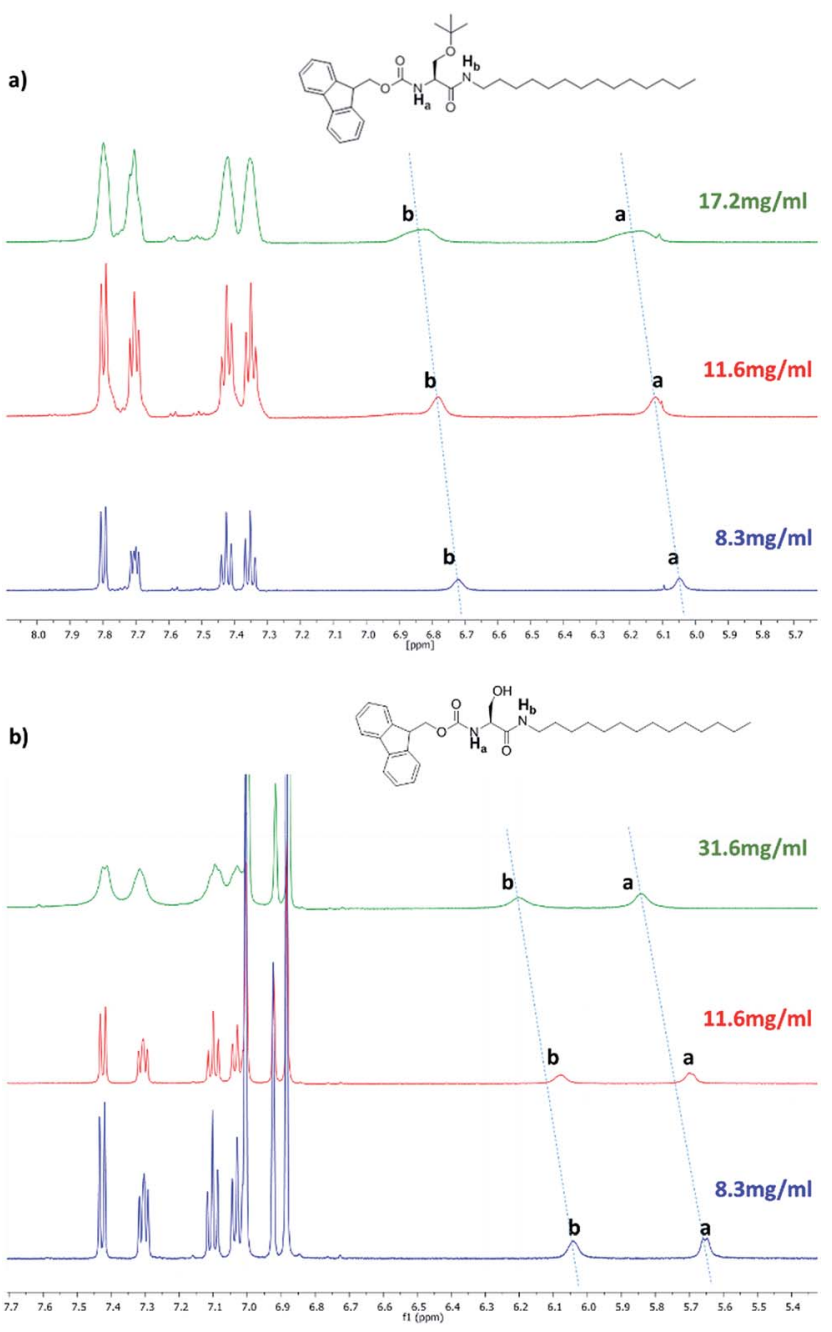

Fig. $4{ }^{1} \mathrm{H}-\mathrm{NMR}$ spectra in solution (blue and red) and in gel phase (green) of 1 in $\left(D_{12}\right)$-cyclohexane (a) and 3 in $\left(D_{8}\right)$-toluene (b).

involved in intermolecular H-bonding, independently of the nature of the gelators' side chain. The samples recorded at the gel state, for both 1 and 3, showed broadening of all resonances

Table 3 Chemical shifts ( $\delta$ ) of the $\mathrm{NH}$ carbamate (a) and the $\mathrm{NH}$ amide (b) in the ${ }^{1} \mathrm{H}$-NMR spectra in solution $\left({ }^{1}\right.$ concentration $=8.3 \mathrm{mg} \mathrm{mL}^{-1}$, ${ }^{2}$ concentration $\left.=11.6 \mathrm{mg} \mathrm{mL}^{-1}\right)$ and in gel phase $\left({ }^{3}\right.$ concentration = $17.2 \mathrm{mg} \mathrm{mL}^{-1}$, ${ }^{4}$ concentration $\left.=31.6 \mathrm{mg} \mathrm{mL}^{-1}\right)$ of 1 in $\left(D_{12}\right)$-cyclohexane and 3 in $\left(D_{8}\right)$-toluene

\begin{tabular}{|c|c|c|}
\hline Compound/solvent & $\begin{array}{l}1 /\left(D_{12}\right)^{-} \\
\text {cyclohexane }\end{array}$ & $\begin{array}{l}3 /\left(D_{8}\right)^{-} \\
\text {toluene }\end{array}$ \\
\hline$\delta$ NH carbamate (a) in solution ${ }^{1}(\mathrm{ppm})$ & 6.04 & 5.76 \\
\hline$\delta \mathrm{NH}$ carbamate (a) in solution ${ }^{2}(\mathrm{ppm})$ & 6.12 & 5.82 \\
\hline$\Delta \delta \mathrm{NH}$ carbamate (a) in solution & 0.08 & 0.06 \\
\hline$\delta$ NH carbamate (a) in gel (ppm) & $6.16^{3}$ & $5.96^{4}$ \\
\hline$\delta \mathrm{NH}$ amide $(\mathbf{b})$ in solution ${ }^{1}(\mathrm{ppm})$ & 6.72 & 6.16 \\
\hline$\delta \mathrm{NH}$ amide (b) in solution ${ }^{2}(\mathrm{ppm})$ & 6.78 & 6.19 \\
\hline$\Delta \delta \mathrm{NH}$ amide $(\mathbf{b})$ in solution & 0.06 & 0.03 \\
\hline$\delta \mathrm{NH}$ amide $(\mathbf{b})$ in gel (ppm) & $6.82^{3}$ & $6.32^{4}$ \\
\hline
\end{tabular}


which was accentuated with time. This is a clear indication that the cross-linking of the SAFINs (and therefore the gelation process) is taking place..$^{54}$ It is important to note that the signals corresponding to the aromatic protons did not experience significant upfield shifts, which are usually associated with the formation of strong aromatic $\pi-\pi$ stacking interactions. However, the presence of the fluorenyl group in the compounds described in this study is critical towards their gelation abilities; it was found that the $N$-benzyloxycarbonyl $(N-\mathrm{Cbz})$ protected analogues $^{55}$ of the lipoamino acids described in this work lacked the ability to form gels in organic solvents (data not shown). These observations seem to agree with recent studies which support the evidence that van der Waals dispersion forces account for attractive interactions between aromatic moieties in organic solvents and become more favorable as the size of the stacking surfaces increase. ${ }^{56}$

FTIR spectroscopic data were obtained for the lipoamino acid gelators in different physical states in order to ascertain if $\mathrm{H}$-bonding was an important factor for gel formation. Previous studies have shown that when organogel formation was promoted by H-bonding, the IR bands associated with the relevant functional groups in the molecule shift to lower wavenumber from those recorded of the gelator free in solution. ${ }^{57,58}$ FTIR spectra of 1 and 3 were recorded as a bulk solid sample (Fig. S5 and S6-ESI $\dagger$ ), as gels in cyclohexane and toluene, respectively, and as the solvated gelator molecules in chloroform solution (Fig. S7-ESI $\dagger$ ). The positions and assignments of the noteworthy IR bands ( $\nu \mathrm{NH}$ and $\nu \mathrm{CO})$ of gelators 1 and 3 in the three states is given in Table 4 . The $\nu \mathrm{OH}$ band of 3 in chloroform solution could not be distinguished from the overlapping solvent bands. No $\nu \mathrm{OH}$ band could be identified for 3 in the gel or bulk states and we would propose that due to $\mathrm{H}$ bonding it has shifted to sufficiently low wavenumber so that it overlaps with the $\nu \mathrm{NH}$ band. Assignments of the CO stretching bands are based on the studies by Fleming et al. on related systems. ${ }^{59}$ The spectra recorded for the bulk and gel state showed similar peak positions for the three bands, whereas all three bands were shifted to higher wavenumber in the solution spectrum. For gelator 1 , the bands for the $\nu \mathrm{NH}, \nu \mathrm{CO}_{\text {carbamate }}$ and $\nu \mathrm{CO}_{\text {amide }}$ shifted to higher frequency by 142,25 and $20 \mathrm{~cm}^{-1}$ respectively between the gel and chloroform solution. For gelator 3, the band associated with the $\nu \mathrm{NH}$ stretch shifts 128 $\mathrm{cm}^{-1}$ between that of the gel and the solution state going from 3299 to $3427 \mathrm{~cm}^{-1}$, while those of the $\nu \mathrm{CO}_{\text {carbamate }}$ and $\nu \mathrm{CO}_{\text {amide }}$ shift 22 and $15 \mathrm{~cm}^{-1}$ respectively. In both cases the magnitudes of the shifts are similar to those recorded for other $\mathrm{H}$-bonded gels $^{58,59}$ and indicate that in the gel and bulk states the $\mathrm{NH}$ groups of one molecule are $\mathrm{H}$-bonding with both the carbamate and amide $\mathrm{CO}$ acceptor group of other gelator molecules.

As there is clear distinction between the spectra of 3 recorded in both solution and the gel state, studies were carried out to directly follow the formation of the gel using IR spectroscopy. In the first study, 3 was dissolved in toluene $(1.3 \mathrm{w} / \mathrm{v} \%)$ which was held at $50{ }^{\circ} \mathrm{C}$, well above the gelation temperature. The solution was transferred into IR solution transmission cell and spectra were recorded over a period of 135 min during which time the cell cooled down to room temperature and gelation occurred (Fig. 5b and S8-ESI $\dagger$ ). The initial spectrum shows bands at 3578 $(\nu \mathrm{OH}), 3404(\nu \mathrm{NH})$ 1727, $1709\left(\nu \mathrm{CO}_{\text {carbamate }}\right)$ and $1681(\mathrm{br})$ $\left(\nu \mathrm{CO}_{\text {amide }}\right) \mathrm{cm}^{-1}$ for 3 in solution in toluene. The splitting and broadening of the CO stretching bands suggests that 3 exists as more than one conformer in toluene. The position and shape of the $\nu \mathrm{OH}$ band indicates that the $\mathrm{OH}$ group is involved in a $\mathrm{H}$ bond interaction intramolecularly or that 3 is present in the toluene solvent as small aggregates at the start of the experiment. Over $135 \mathrm{~min}$ as gelation occurred these peaks decrease in intensity and new peaks associated with the formation of $\mathrm{H}$ bonds are observed to concurrently grow at $3299(\nu \mathrm{NH}$ and $\nu \mathrm{OH}), 1687$ ( $\left.\nu \mathrm{CO}_{\text {carbamate }}\right)$ and $1651\left(\nu \mathrm{CO}_{\text {amide }}\right) \mathrm{cm}^{-1}$. The presence of a number of isosbestic points indicate clean conversion. An estimation of $45 \%$ conversion of 3 into the gel state was determined from the decrease in absorbance of the starting material bands over the 135 min time period. Similar results were observed, with the exception of the absence of a $\nu \mathrm{OH}$ band in the starting spectrum, when the gelation of $\mathbf{1}$ in cyclohexane was followed using FTIR (Fig. 5a and S9-ESI $\dagger$ ).

A further study was then carried out in which a room temperature toluene solution of $3(2.6 \mathrm{w} / \mathrm{v} \%)$ was placed in the solution plate of the FTIR-ATR optics and spectra were recorded over a period of approximately $1 \mathrm{~h}$ (Fig. S10-ESI $\dagger$ ). Initially no compound bands are observed in the spectra of the solution but as the gel formed, bands appeared to 'grow-in' at 3290, 1692 and $1651 \mathrm{~cm}^{-1}$. This difference in intensity of the FTIR bands between the solution and gel state has been observed by other authors and is proposed to be due to an increase in the concentration of 3 close to the ATR crystal as the gel forms. ${ }^{57,60}$ The increase in intensity of the bands for gelator 3 as a function of time are plotted in Fig. S11-ESI. $\dagger$ It is clear that there is an

Table 4 Position of characteristic IR bands of the lipoamino acids 1 and 3 in the solid state, gel state and $\mathrm{CHCl}_{3}$ solution. * $\nu(\mathrm{OH})$ band not distinguishable from overlapping solvent peaks. ** possibly also includes an overlapping $\nu(\mathrm{OH})$ band

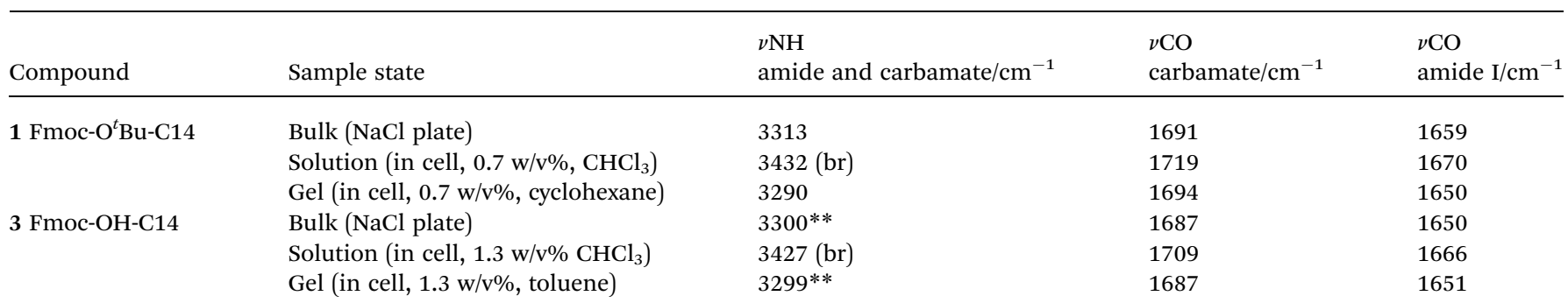


a)

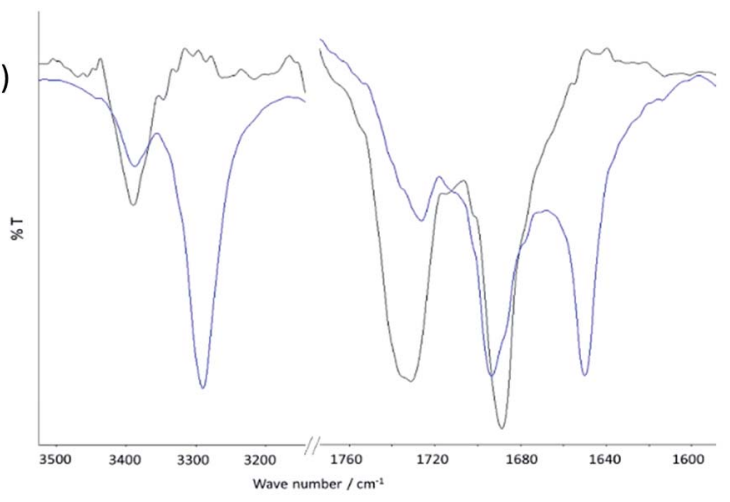

b)

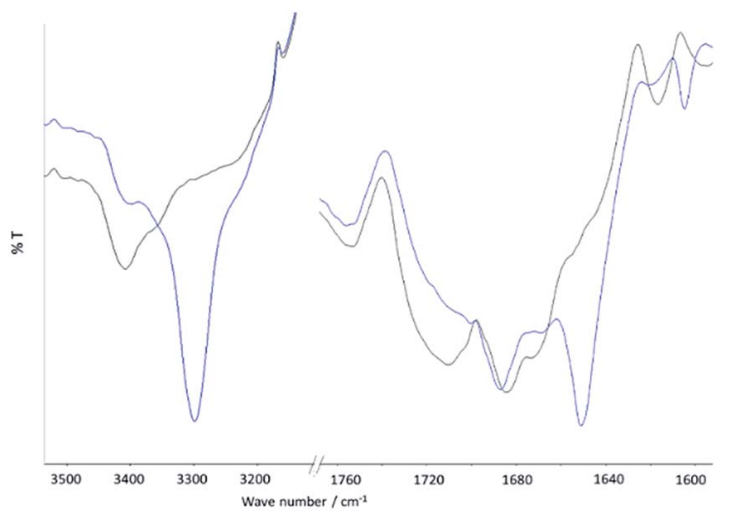

Fig. 5 Partial FTIR spectra of (a) lipoamino acid $1(0.7 \mathrm{w} / \mathrm{v} \%)$ in cyclohexane and (b) lipoamino acid $3(1.3 \mathrm{w} / \mathrm{v} \%)$ in toluene. Spectra at 0 min: solution phase (black); spectra at 135 min: gel phase (blue).

induction period for gelation and this is consistent with there being a free energy barrier to the nucleation process that is necessary for the gel phase to grow.

\subsection{Powder X-ray diffraction data}

Powder X-ray diffraction (XRD) measurements of compounds $\mathbf{1}$, 2 (xerogels from hexane gels) and 3, $\mathbf{4}$ (xerogels from toluene gels) were carried out to further investigate the structure of the self-assembled gelators (Fig. S12-ESI $\dagger$ ). The spacings $d$ were calculated from the Bragg's equation (for full list see Table S1ESI†). In all diffractograms, a prominent reflection in the wide angle region corresponding to $d$ spacing values ranging from 4.0-4.5 ̊ can be clearly observed. It can be attributed to the intermolecular distances of one molecule of gelator and the next, bonded through a network of H-bonds, stacking of the fluorenyl moieties and van der Waals interactions between the alkyl chains. The peaks observed for all the xerogels were broad, however the diffractograms of the $\mathrm{C}-18$ derivatives (gelators 2 and 4) showed more defined reflections than their C-14 counterparts. This suggest that the extended alkyl chain imposes more order in the gel structures. The diffraction patterns observed for the hexane xerogel of gelator 2 and the toluene xerogel of gelator 4 differ significantly, which indicates that the molecular organization in the self-assembled materials is also different. This is in good agreement with the clearly different morphologies observed in the SEM images of the xerogels
(Fig. 3). Although some of the observed peaks for lower $2 \theta$ values seem to follow a ratio of $1: 1 / 2: 1 / 3: 1 / 4$, which could correspond to a lamellar organization, it was not possible to identify such arrangement conclusively. Similar difficulties in the interpretation of XRD data have been reported for amphiphilic organogelators. ${ }^{61}$ In the present study, it is possible that a number of self-assembled structures coexist in the xerogel.

Parallel and antiparallel arrangements which can lead to the formation of fibres have been previously proposed for gelators containing fluorenyl groups..$^{34,35,62}$ A schematic representation of how such patterns could arise in the gelators described herein is depicted in Fig. 6a and b. From this, it is clear how the relative orientations of the lipoamino acids can lead to very different extended supramolecular structures: derivatives $\mathbf{1}$ and 2 may favour an antiparallel arrangement, which would accommodate the bulky and hydrophobic $O$-tert-butyl group on the side chain, while gelators $\mathbf{3}$ and $\mathbf{4}$, with a smaller hydroxyl group, may adopt a parallel alignment. These considerations could account for the observed differences in morphology and rheological behaviour of the gels described in this study. It has been previously reported that the presence of hydroxyl groups in the structure of amphiphilic gelators affect their ability to induce the formation of a supramolecular gels. ${ }^{23,61,63}$ These studies have shown that hydroxyl groups can affect the $\mathrm{H}$ bonding network between the gelator molecules through the formation of intra or intermolecular $\mathrm{H}$ bonds or through steric

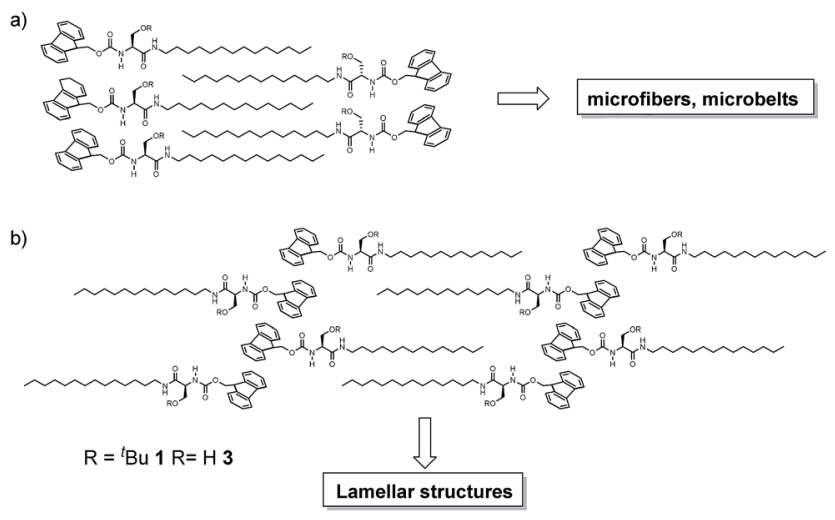

c)

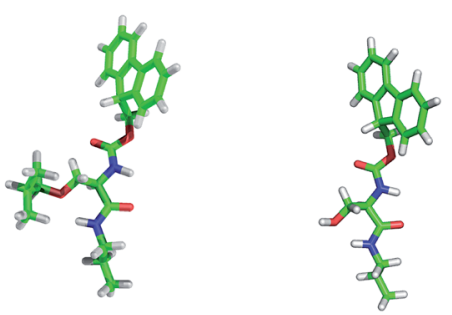

Fig. 6 (a) Schematic representation of parallel alignment proposed for the self-assembly of gelators 3 and 4 (not depicted); (b) schematic representation of antiparallel alignment proposed for the selfassembly of gelators 1 and 2 (not depicted); (c) minimized structures of the amino acid core of the O-tert-butyl (left) and the hydroxyl (right) gelators. All geometry optimisations have been performed using the trust radius image minimization algorithm, at the B3LYP/def2-SVP level of theory within the Resolution of the Identity (RI) approximation, with version 6.6 of TURBOMOLE GmbH. 
factors and therefore influence their self-assembly. The conformations of the amino acid core of both the O-tert-butylated and hydroxylated gelators do not differ significantly, as shown in the minimized structures in Fig. 6c. The presence of an intramolecular $\mathrm{H}$-bond can be observed in both structures: this leads to similar patterns in the presentation of the $\mathrm{H}$ bonding groups, which are not affected by the nature of the functional group in the side chain.

\subsection{Phase selective gelation and removal of aromatic dyes from water}

LMWG capable of performing organogelation in biphasic mixtures have been investigated for a range of environmental applications. ${ }^{\mathbf{6 4 , 6 5}}$ The lipoamino acids 1-4 were able to selectively gel the organic phase in biphasic aqueous mixtures. The gelation potential of these compounds was investigated considering a heating-cooling cycle of the biphasic mixture (Fig. 7a and S13$\mathrm{ESI} \dagger$ ). Phase selective gelation also occurred when the gelator was applied as a warm organic solution to a biphasic mixture of water and the organic solvent (Fig. 7b). The physical integrity of the gels permitted their easy handling and simple removal from the mixture (Fig. 7c-e and S13-ESI $\dagger$ ). The robustness of these gels allowed them to be moulded into different shapes (Fig. S14-ESI $\dagger$ ). Interestingly, the gels also showed self-healing capabilities when severed (Fig. S13 and S15-ESI $\dagger$ ).

The removal of toxic dyes from aqueous solutions using the lipoamino acid gelators was investigated. The elimination of aromatic pollutants using LMWG has been previously reported. ${ }^{36,66}$ The hydrophilic dye rhodamine $\mathrm{B}(\mathrm{RhB})$ is often used as a "proof of concept" for this application. ${ }^{67}$ Thus, an aqueous solution of $\mathrm{RhB}(0.03 \mathrm{mM})$ was treated with solutions of $\mathbf{1}(0.7 \mathrm{w} /$ $\mathrm{v} \%$ in hexane) and 3 (1.3 w/v\% in toluene). The mixture was allowed to settle and once the gels were formed, they were separated from the water either manually or by gravity filtration. UV-vis absorption spectra of the aqueous phase were recorded after treatment (Fig. 8). The purification efficiency $(E)$ was determined according to eqn (1) ( $A_{\mathrm{o}}$ and $A$ refer to absorption intensity at $553 \mathrm{~nm}$, Table 5).

$$
E=\left(A_{\mathrm{o}}-A\right) \times 100 / A_{\mathrm{o}}
$$

Controls were prepared whereby the RhB was treated with only toluene or hexane. An evident colour change in the

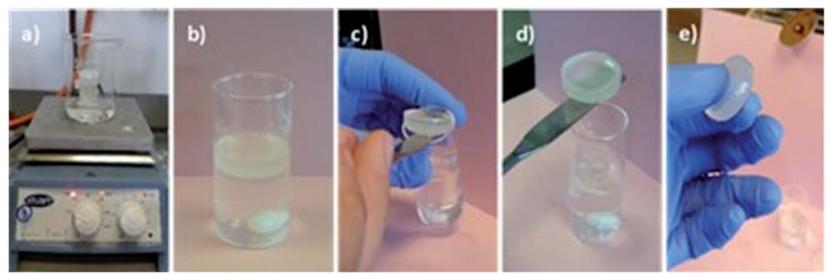

Fig. 7 Phase selective gelation of toluene induced by lipoamino acid 3 $(1.3 \mathrm{w} / \mathrm{v} \%)$ : gelation of toluene in a biphasic aqueous mixture by gelator 3 either by heating-cooling cycle (a) or by direct treatment (b); (c)-(e) removal of the toluene gel.

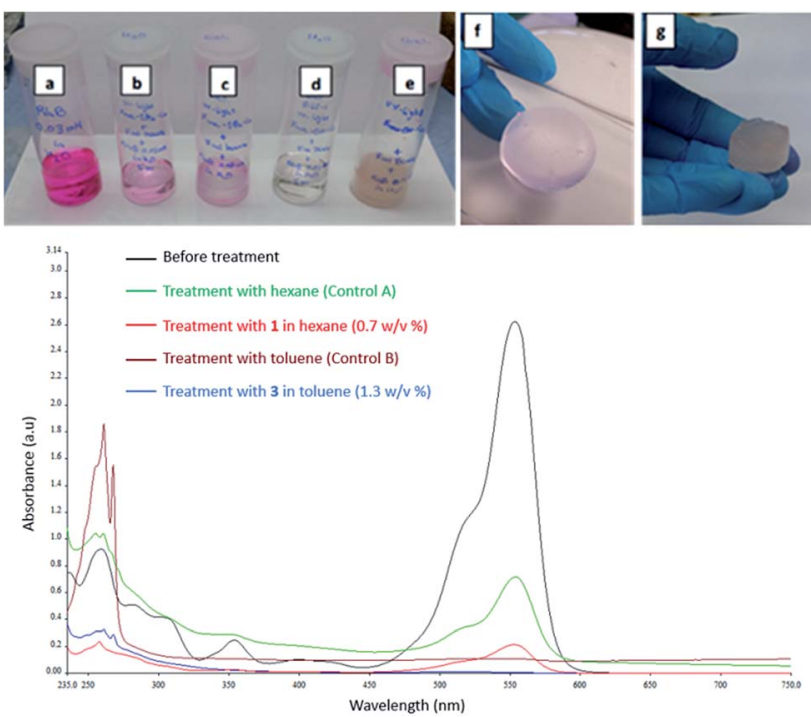

Fig. 8 Removal of RhB from aqueous solution by phase selective gelation: top: aqueous solution of RhB [0.03 mM] (a); aqueous solution of RhB after treatment with 1 in hexane (b); after hexane extraction (c); after treatment with 3 in toluene (d); after toluene extraction (e); isolated gels: 1 in hexane (f), 3 in toluene (g) after treatment. Bottom: UVvis absorption spectra of $\mathrm{RhB}$ aqueous solution before and after dye removal by phase selective gelation. Solutions of 1 and 3 were prepared at CGC.

aqueous phase after treatment (from dark pink to light pink/ colourless) indicated that the dye was extracted to the organic phase. The purification efficacy was found to be $100 \%$ when the aqueous RhB solution was treated with gelator 3 in toluene, whereas it was $92 \%$ with gelator 1 in hexane. While the controls also removed the dye from the aqueous phase, the purification efficiency in these cases could not be determined accurately since residual organic solvent disrupted the spectra baseline.

These results indicate that the formation of the gel facilitates the removal of the dye from the aqueous phase and improves the extraction process. The entrapment of $\mathrm{RhB}$ in the gel network resulted in an increase in their $T_{\mathrm{gs}}\left(45-55^{\circ} \mathrm{C}\right.$ for the hexane gel of 1 compared to $40-47^{\circ} \mathrm{C}$ in absence of RhB, 45$60{ }^{\circ} \mathrm{C}$ for the toluene gel of 3 compared to $35-39^{\circ} \mathrm{C}$ in absence of $\mathrm{RhB}$ ). This remarkable increase, particularly for the toluene gel, seem to indicate that RhB was acting as a gel dopant. This

Table 5 Determination of purification efficiency: UV-vis absorbance (at $553 \mathrm{~nm}$ ) of aqueous phase and [RhB] before and after purification

\begin{tabular}{llll}
\hline Aqueous phase & $\begin{array}{l}\text { Absorbance } \\
\text { (a.u.) }\end{array}$ & $\begin{array}{l}{[\mathrm{RhB}]} \\
(\mathrm{mM})\end{array}$ & $\begin{array}{l}E \\
(\%)\end{array}$ \\
\hline Before treatment & 2.62 & 0.030 & - \\
Treatment with hexane (control A) & 0.71 & $\mathrm{na}^{a}$ & - \\
Treatment with 1 in hexane $(0.7 \mathrm{w} / \mathrm{v} \%)$ & 0.21 & 0.0024 & 92 \\
Treatment with toluene (control B) & 0.10 & $\mathrm{na}^{a}$ & - \\
Treatment with 3 in toluene $(1.3 \mathrm{w} / \mathrm{v} \%)$ & 0.00 & 0.0000 & 100
\end{tabular}

${ }^{a}$ The [RhB] in the aqueous phase could not be determined accurately due to residual organic solvent affecting the baseline. 
observation could lead to future developments of the lipoamino acid based gels whereby doping agents structurally similar to RhB could be used to modulate the gels properties. ${ }^{68}$ The removal of an anionic dye (methyl orange) was also investigated. It was found that both gelator $\mathbf{1}$ and $\mathbf{3}$ facilitated the removal of methyl orange from the aqueous phase into hexane and toluene, respectively. However, the purification efficacies are slightly inferior compared to those observed for the removal of rhodamine $\mathrm{B}$, possibly due to the lower solubility of methyl orange in toluene and hexane (Fig. S16-ESI $\dagger$ ).

\section{Conclusions}

It is becoming evident that minor structural changes can greatly impact the gelation abilities of LMWG. This study has focused on how the replacement of the side chain functional groups of $N$-Fmoc-L-serine lipoamino acids (from $O$-tert-butyl to hydroxyl) causes differences in solubility and self-assembly properties to achieve the selective gelation of aliphatic or aromatic solvents. Steric effects lead to distinct self-assembly patterns which in turn define the morphology of the SAFINs and the characteristics of the gels. While the elongation of the alkyl chain length improves the physical properties of the gels, it diminishes the ability to differentiate between aliphatic and aromatic solvent gelation. The lipoamino acid were also highly effective organogelators of biphasic mixtures and enhanced the removal of aromatic dyes from aqueous solutions.

\section{Experimental section}

\subsection{Materials and instrumentation}

All chemicals purchased were reagent grade and used without further purification, unless stated otherwise. Anhydrous dichloromethane was freshly distilled over $\mathrm{CaH}_{2}$. Reactions were monitored by thin layer chromatography (TLC) on Merck Silica Gel F254 plates. Flash chromatography was performed with Merck Silica Gel 60. NMR spectra were obtained for solutions in $\mathrm{CDCl}_{3}$ with a Bruker Ascend 500 spectrometer and residual solvent peak was used as the internal standard. Chemical shifts $(\delta)$ are reported in ppm. Optical rotations were obtained using an AA-100 polarimeter and are uncorrected. Mass spectra were recorded on an Agilent-LC 1200 Series coupled to a 6210 Agilent Time-Of-Flight (TOF) mass spectrometer equipped with an electrospray source both positive and negative $\left(\mathrm{ESI}^{+/-}\right.$). SEM images were taken on a HITACHI S3200N Scanning Electron Microscope. Rheological measurements were performed on a strain-controlled Anton Paar Physica MCR301 rheometer using PP15/Al and a P-PTD 200/TG + HPTD200. DSC analysis was carried out on a PerkingElmer Pyris 6 Differential Scanning Calorimetry. The stainless steel crucibles for DSC (pan: $\Phi 6.7 \times 2.6 \mathrm{~mm} \&$ lid: $\Phi 7 \times 2 \mathrm{~mm}$ ), temperature range: $-50-280{ }^{\circ} \mathrm{C}$ were supplied for Shanghai DiBo Laboratory Equipment Co., Ltd. FT-IR spectra were recorded with a PerkinElmer precisely (Spectrum 100). UV-vis spectra were recorded in a PerkinElmer precisely Lambda $35 \mathrm{UV} /$ vis spectrometer. XRPD data were obtained with a PANalytical X'Pert MPD PRO diffractometer.

\subsection{General procedure for amide coupling reaction}

To a solution of Fmoc-O-tert-butyl-L-serine $(0.60 \mathrm{~g}, 1.56 \mathrm{mmol})$ in anhydrous dichloromethane $(30 \mathrm{~mL})$, diisopropylcarbodiimide $(0.29 \mathrm{~mL}, 1.87 \mathrm{mmol})$ was added under a nitrogen atmosphere and at room temperature. After $15 \mathrm{~min}$, the corresponding amine (for the synthesis of lipoamino acid 1: tetradecylamine, $0.40 \mathrm{~g}, 1.87 \mathrm{mmol}$; for the synthesis of lipoamino acid 2: octadecylamine, $0.50 \mathrm{~g}, 1.87 \mathrm{mmol}$ ) was then added and left to stir for $18 \mathrm{~h}$. The reaction mixture was then washed with $0.5 \mathrm{M} \mathrm{HCl}(30 \mathrm{~mL})$, saturated aqueous $\mathrm{NaHCO}_{3}(20$ $\mathrm{mL}$ ) and brine $(20 \mathrm{~mL})$. The organic layer was dried over $\mathrm{Na}_{2} \mathrm{SO}_{4}$, filtered and the solvent was evaporated under reduced pressure. The crude was purified by column chromatography (petroleum ether : ethyl acetate $2: 1$ to $1: 1$ ) to give the product as a white solid (lipoamino acid 1: $0.85 \mathrm{~g}$, 95\%; lipoamino acid 2: $0.87 \mathrm{~g}$, $88 \%)$.

$\mathrm{N}$-(9-Fluorenylmethyloxycarbonyl)-O-tert-butyl-L-serine tetradecylamide (Fmoc-O $\left.{ }^{t} \mathbf{B u}-\mathbf{C}-14\right) \quad 1 .{ }^{69} R_{\mathrm{f}}=0.94$ (petroleum ether : ethyl acetate $1: 1) ;[\alpha]_{\mathrm{D}}^{22}+9\left(c 1.0, \mathrm{CHCl}_{3}\right) ;{ }^{1} \mathrm{H}$ NMR $(500$ $\left.\mathrm{MHz}, \mathrm{CDCl}_{3}\right): \delta 7.76(\mathrm{~d}, J=7.6 \mathrm{~Hz}, 2 \mathrm{H}, \mathrm{H}-\mathrm{Ar}), 7.60(\mathrm{~d}, J=7.3 \mathrm{~Hz}$, $2 \mathrm{H}, \mathrm{H}-\mathrm{Ar}$ ), 7.39 (at, $J=7.4 \mathrm{~Hz}, 2 \mathrm{H}, \mathrm{H}-\mathrm{Ar}$ ), 7.31 (at, $J=7.5 \mathrm{~Hz}, 2 \mathrm{H}$, $\mathrm{H}-\mathrm{Ar}$ ), 6.59 (bs, 1H, $\mathrm{NHCH}_{2}$ ), 5.79 (bs, 1H, NH-Fmoc), 4.40 (d, $J=$ $6.9 \mathrm{~Hz}, 2 \mathrm{H}$, Fmoc-OCH $\mathrm{OH}_{2}$ ) $4.22(\mathrm{t}, J=7.1 \mathrm{~Hz}, 1 \mathrm{H}$, Fmoc$\left.\mathrm{OCH}_{2} \mathrm{CH}\right), 4.16-4.17(\mathrm{~m}, 1 \mathrm{H}, \mathrm{H}-\alpha), 3.81(\mathrm{dd}, J=3.8 \mathrm{~Hz}, J=7.9 \mathrm{~Hz}$, $1 \mathrm{H}, \mathrm{H}-\beta), 3.36\left(\mathrm{dd}, J=3.8 \mathrm{~Hz}, J=7.6 \mathrm{~Hz}, 1 \mathrm{H}, \mathrm{H}-\beta^{\prime}\right), 3.27-3.24(\mathrm{~m}$, $2 \mathrm{H}, \mathrm{NHCH}_{2}$ ), 1.50-1.48 (m, 2H, $\left.\mathrm{NHCH}_{2} \mathrm{CH}_{2}\right), 1.29-1.22$ (bs, $22 \mathrm{H}$, $\left.\mathrm{NHCH}_{2} \mathrm{CH}_{2}\left(\mathrm{CH}_{2}\right)_{11} \mathrm{CH}_{3}\right), 1.20\left(\mathrm{~s}, 9 \mathrm{H},{ }^{t} \mathrm{Bu}\right), 0.88(\mathrm{t}, J=6.8 \mathrm{~Hz}, 3 \mathrm{H}$, $\mathrm{CH}_{3}$ ); ${ }^{13} \mathrm{C}$ NMR (125 MHz, $\left.\mathrm{CDCl}_{3}\right): \delta 169.0(\mathrm{CONH}), 155.1$ (COFmoc), 142.8, 142.7, 140.3, 140.2 (C-Ar), 127.7, 126.7, 126.0, 124.1, 124.0, 119.9, 118.9, 118.7 (CH-Ar), $73.1\left(\left(\mathrm{CH}_{3}\right)_{3} \mathrm{C}\right), 66.0$ $\left(\mathrm{CH}_{2}-\beta\right), 60.8\left(\mathrm{CH}_{2}-\mathrm{Fmoc}\right), 53.4(\mathrm{CH}-\alpha), 46.2$ (CH-Fmoc), 38.5, 30.9 $\left(\mathrm{CH}_{2}\right), 29.8\left(\mathrm{C}\left(\mathrm{CH}_{3}\right)_{3}\right), 28.67,28.64,28.63,28.58,28.53,28.51$, 28.3, 28.2, 26.4, 25.8, $21.7\left(\mathrm{CH}_{2}\right), 13.1\left(\mathrm{CH}_{3}\right) . \mathrm{IR} \nu_{\max }(\mathrm{NaCl}$, film in DCM): $3313.85(\mathrm{~N}-\mathrm{H}), 1691.90($ Fmoc-C $=\mathrm{O}), 1659.78(\mathrm{NH}-\mathrm{C}=\mathrm{O})$, $\mathrm{cm}^{-1}$; HRMS $m / z\left(\mathrm{ESI}^{+}\right)$calc. for $\mathrm{C}_{36} \mathrm{H}_{54} \mathrm{~N}_{2} \mathrm{O}_{4}$ : 578.4083; found $579.4148\left[\mathrm{M}+\mathrm{H}^{+}\right], 601.3966\left[\mathrm{M}+\mathrm{Na}^{+}\right]$.

$\boldsymbol{N}$-(9-Fluorenylmethyloxycarbonyl)-O-tert-butyl-L-serine octadecylamide (Fmoc-O ${ }^{t}$ Bu-C-18) 2. $R_{\mathrm{f}}=0.91$ (petroleum ether: ethyl acetate $1: 1) ;[\alpha]_{\mathrm{D}}:+9\left(c 1.0 \mathrm{CHCl}_{3}\right) ;{ }^{1} \mathrm{H}$ NMR $(500 \mathrm{MHz}$, $\left.\mathrm{CDCl}_{3}\right): \delta 7.76(\mathrm{~d}, J=7.6 \mathrm{~Hz}, 2 \mathrm{H}, \mathrm{H}-\mathrm{Ar}), 7.60(\mathrm{~d}, J=7.3 \mathrm{~Hz}, 2 \mathrm{H}, \mathrm{H}-$ Ar), 7.40 (at, $J=7.4 \mathrm{~Hz}, 2 \mathrm{H}, \mathrm{H}-\mathrm{Ar}$ ), 7.31 (at, $J=7.5 \mathrm{~Hz}, 2 \mathrm{H}, \mathrm{H}-\mathrm{Ar}$ ), $6.58\left(\mathrm{~s}, 1 \mathrm{H}, \mathrm{NHCH}_{2}\right), 5.77$ (s, 1H, NH-Fmoc), 4.40 (d, J=6.9 Hz, $2 \mathrm{H}, \mathrm{Fmoc}-\mathrm{OCH}_{2} \mathrm{CH}$ ), 4.22 (t, $J=7.1 \mathrm{~Hz}, 1 \mathrm{H}, \mathrm{Fmoc}_{-} \mathrm{OCH}_{2} \mathrm{CH}$ ), 4.16 (bs, $1 \mathrm{H}, \mathrm{H}-\alpha$ ), 3.81 (dd, $J=3.8 \mathrm{~Hz}, J=7.9 \mathrm{~Hz}, 1 \mathrm{H}, \mathrm{H}-\beta$ ), 3.35 (dd, $\left.J=3.8 \mathrm{~Hz}, J=7.6 \mathrm{~Hz}, 1 \mathrm{H}, \mathrm{H}-\beta^{\prime}\right), 3.26-3.24\left(\mathrm{~m}, 2 \mathrm{H}, \mathrm{NHCH}_{2}\right.$ ), 1.50-1.48 (m, 2H, $\mathrm{NHCH}_{2} \mathrm{CH}_{2}$ ), 1.28-1.25 (bs, 30H, $\mathrm{NHCH}_{2}$ $\left.\mathrm{CH}_{2}\left(\mathrm{CH}_{2}\right)_{15} \mathrm{CH}_{3}\right), 1.20(\mathrm{~s}, 9 \mathrm{H}, t-\mathrm{Bu}), 0.88\left(\mathrm{t}, J=6.8 \mathrm{~Hz}, 3 \mathrm{H}, \mathrm{CH}_{3}\right)$; ${ }^{13} \mathrm{C} \mathrm{NMR}\left(125 \mathrm{MHz}, \mathrm{CDCl}_{3}\right.$ ): $\delta 170.1$ (CONH), 156.1 (CO-Fmoc), 143.9, 143.8, 141.3 (C-Ar), 127.7, 127.1, 125.13, 125.10, 120.0 (CH-Ar), $74.2\left(\left(\mathrm{CH}_{3}\right)_{3} \mathrm{C}\right), 67.0\left(\mathrm{CH}_{2}-\beta\right), 61.9\left(\mathrm{CH}_{2}-\mathrm{Fmoc}\right), 54.4$ (CH- $\alpha$ ), 47.2 (CH-Fmoc), 39.6, $31.9\left(\mathrm{CH}_{2}\right), 29.7\left(\mathrm{C}\left(\mathrm{CH}_{3}\right)_{3}\right), 29.68$, 29.67, 29.66, 29.62, 29.57, 29.54, 29.4, 29.3, 27.5, 26.9, 22.7 $\left(\mathrm{CH}_{2}\right), 14.1\left(\mathrm{CH}_{3}\right)$; IR $\nu_{\max }(\mathrm{NaCl}$, film in DCM): $3311.35(\mathrm{~N}-\mathrm{H})$, 1691.41 (Fmoc-C $=\mathrm{O}), 1659.67(\mathrm{NH}-\mathrm{C}=\mathrm{O}) \mathrm{cm}^{-1}$; HRMS m/z $\left(\mathrm{ESI}^{+}\right.$) calc. for $\mathrm{C}_{40} \mathrm{H}_{62} \mathrm{~N}_{2} \mathrm{O}_{4}$ : 634.4709; found 635.4786 [M+ $\left.\mathrm{H}^{+}\right]$, $657.4602\left[\mathrm{M}+\mathrm{Na}^{+}\right]$. 


\subsection{General procedure for $\boldsymbol{O}$-tert-butyl ether deprotection}

To a solution of Fmoc-O-tert-butyl-L-serine amide (tetradecyl amide 1: $437 \mathrm{mg}, 0.76 \mathrm{mmol}$; octadecylamide 2: $380 \mathrm{mg}, 0.59$ $\mathrm{mmol})$ in DCM $(20 \mathrm{~mL})$ TFA $(0.86 \mathrm{~mL}, 11.32 \mathrm{mmol}$ for amide $\mathbf{1}$; $0.68 \mathrm{~mL}, 8.95 \mathrm{mmol}$ for amide 2 ) was added at room temperature. The reaction mixture was stirred for $15 \mathrm{~h}$, diluted with brine and extracted with ethyl acetate $(3 \times 30 \mathrm{~mL})$. The combined organic layers were dried over $\mathrm{Na}_{2} \mathrm{SO}_{4}$, filtered and the solvent was evaporated under reduced pressure. The crude was purified by column chromatography (petroleum ether : ethyl acetate $3: 1$ to $1: 1$ ) to give the product as a white solid (lipoamino acid 3: $641 \mathrm{mg}$, 85\%; lipoamino acid 4: $176 \mathrm{mg}$, $51 \%)$.

$\mathrm{N}$-(9-Fluorenylmethyloxycarbonyl)-L-serine tetradecylamide (Fmoc-OH-C-14) 3. $R_{\mathrm{f}}=0.39$ (petroleum ether : ethyl acetate $1: 1) ;[\alpha]_{\mathrm{D}}:-6\left(c 1.0 \mathrm{CHCl}_{3}\right) ;{ }^{1} \mathrm{H}$ NMR $\left(500 \mathrm{MHz}, \mathrm{CDCl}_{3}\right): \delta 7.77$ (d, $J=7.6 \mathrm{~Hz}, 2 \mathrm{H}, \mathrm{H}-\mathrm{Ar}$ ), 7.58 (d, $J=7.5 \mathrm{~Hz}, 2 \mathrm{H}, \mathrm{H}-\mathrm{Ar}$ ), 7.41 (at, $J$ $=7.4 \mathrm{~Hz}, 2 \mathrm{H}, \mathrm{H}-\mathrm{Ar}$ ), 7.32 (at, $J=7.5 \mathrm{~Hz}, 2 \mathrm{H}, \mathrm{H}-\mathrm{Ar}), 6.49$ (s, $1 \mathrm{H}$, $\mathrm{NHCH}_{2}$ ), 5.82 (s, 1H, NH-Fmoc), 4.44 (d, $J=6.9 \mathrm{~Hz}, 2 \mathrm{H}$, Fmoc$\left.\mathrm{OCH}_{2} \mathrm{CH}\right), 4.22$ (t, $\left.J=6.9 \mathrm{~Hz}, 1 \mathrm{H}, \mathrm{Fmoc}-\mathrm{OCH}_{2} \mathrm{CH}\right), 4.15$ (bs, $1 \mathrm{H}$, $\mathrm{H}-\alpha), 3.66(\mathrm{dd}, J=6.3 \mathrm{~Hz}, J=7 \mathrm{~Hz}, 1 \mathrm{H}, \mathrm{H}-\beta), 3.24(\mathrm{dd}, J=6.3 \mathrm{~Hz}$, $\left.J=7.2 \mathrm{~Hz}, 1 \mathrm{H}, \mathrm{H}-\beta^{\prime}\right), 3.05-3.03$ (m, 2H, $\mathrm{NHCH}_{2}$ ), 1.50-1.48 (m, $2 \mathrm{H}, \mathrm{NHCH}_{2} \mathrm{CH}_{2}$ ), 1.25-1.23 (bs, $22 \mathrm{H}, \mathrm{NHCH}_{2} \mathrm{CH}_{2}\left(\mathrm{CH}_{2}\right)_{11} \mathrm{CH}_{3}$ ), $0.88\left(\mathrm{t}, J=6.8 \mathrm{~Hz}, 3 \mathrm{H}, \mathrm{CH}_{3}\right) ;{ }^{13} \mathrm{C} \mathrm{NMR}\left(125 \mathrm{MHz} \mathrm{CDCl}_{3}\right): \delta 175.5$ (CONH), 158.4 (CO-Fmoc), 143.65, 143.61, 141.3, 136.8 (C-Ar), 127.8, 127.1, 124.9, 120.1 (CH-Ar), $67.3\left(\mathrm{CH}_{2}-\beta\right), 62.9\left(\mathrm{CH}_{2}-\right.$ Fmoc), 54.9 (CH- $\alpha$ ), 47.1 (CH-Fmoc), 39.6, 31.9, 30.9, 29.69, 29.67, 29.65, 29.59, 29.54, 29.40, 29.36, 29.2, 26.8, $22.7\left(\mathrm{CH}_{2}\right)$, $14.1\left(\mathrm{CH}_{3}\right)$; IR $\nu_{\max }(\mathrm{NaCl}$, film in DCM): $3300.25(\mathrm{~N}-\mathrm{H}), 1687.57$ (Fmoc-C $=\mathrm{O}), 1650.66(\mathrm{NH}-\mathrm{C}=\mathrm{O}) \mathrm{cm}^{-1}$; HRMS $\mathrm{m} / z\left(\mathrm{ESI}^{+}\right)$calc. for $\mathrm{C}_{32} \mathrm{H}_{46} \mathrm{~N}_{2} \mathrm{O}_{4}$ : 522.3457; found $523.3553\left[\mathrm{M}+\mathrm{H}^{+}\right], 545.3374$ $\left[\mathrm{M}+\mathrm{Na}^{+}\right]$.

$\mathrm{N}$-(9-Fluorenylmethyloxycarbonyl)-L-serine octadecylamide (Fmoc-OH-C-18) 4. $R_{\mathrm{f}}=0.42$ (petroleum ether : ethyl acetate $1: 1) ;[\alpha]_{\mathrm{D}}:-4\left(c 1.03 \mathrm{CHCl}_{3}\right) ;{ }^{1} \mathrm{H} \mathrm{NMR}\left(500 \mathrm{MHz}, \mathrm{CDCl}_{3}\right): \delta 7.77$ (d, $J=7.6 \mathrm{~Hz}, 2 \mathrm{H}, \mathrm{H}-\mathrm{Ar}$ ), 7.58 (d, $J=7.5 \mathrm{~Hz}, 2 \mathrm{H}, \mathrm{H}-\mathrm{Ar}$ ), 7.41 (at, $J=7.5 \mathrm{~Hz}, 2 \mathrm{H}, \mathrm{H}-\mathrm{Ar}$ ), 7.32 (at, $J=7.3 \mathrm{~Hz}, 2 \mathrm{H}, \mathrm{H}-\mathrm{Ar}$ ), 6.47 (s, $1 \mathrm{H}$, $\mathrm{NHCH}_{2}$ ), 5.80 (s, 1H, NH-Fmoc), 4.44 (d, $J=6.9 \mathrm{~Hz}, 2 \mathrm{H}$, Fmoc$\mathrm{OCH}_{2} \mathrm{CH}$ ), 4.22 (t, $J=6.9 \mathrm{~Hz}, 1 \mathrm{H}$, Fmoc-OCH $\left.{ }_{2} \mathrm{CH}\right), 4.15$ (bs, $1 \mathrm{H}$, $\mathrm{H}-\alpha$ ), $3.66(\mathrm{dd}, J=6.3 \mathrm{~Hz}, J=7.1 \mathrm{~Hz}, 1 \mathrm{H}, \mathrm{H}-\beta), 3.25$ (dd, $J=$ $\left.6.2 \mathrm{~Hz}, J=7 \mathrm{~Hz}, 1 \mathrm{H}, \mathrm{H}-\beta^{\prime}\right), 2.99-2.97$ (m, 2H, $\mathrm{NHCH}_{2}$ ), 1.50-1.48 (m, 2H, $\mathrm{NHCH}_{2} \mathrm{CH}_{2}$ ), 1.25-1.23 (bs, 30H, $\mathrm{NHCH}_{2} \mathrm{CH}_{2}\left(\mathrm{CH}_{2}\right)_{15^{-}}$ $\left.\mathrm{CH}_{3}\right), 0.88\left(\mathrm{t}, J=6.8 \mathrm{~Hz}, 3 \mathrm{H}, \mathrm{CH}_{3}\right) ;{ }^{13} \mathrm{C} \mathrm{NMR}\left(125 \mathrm{MHz}, \mathrm{CDCl}_{3}\right)$ : $\delta 170.8$ (CONH), 161.1 (CO-Fmoc), 143.66, 143.62, 141.3, 134.7 (C-Ar), 127.8, 127.1, 125.0, 120.1 (CH-Ar), $67.3\left(\mathrm{CH}_{2}-\beta\right), 62.9$ ( $\mathrm{CH}_{2}$-Fmoc), 55.1 ( $\mathrm{CH}-\alpha$ ), 47.1 (CH-Fmoc), 41.1, 39.6, 38.2, 36.2, 31.9, 30.4, 29.7, 29.6, 29.58, 29.55, 29.49, 29.40, 29.3, 29.27, 29.25, 29.15, 26.9, 26.8, $22.7\left(\mathrm{CH}_{2}\right), 14.1\left(\mathrm{CH}_{3}\right)$; IR $\nu_{\max }(\mathrm{NaCl}$, film in DCM): $3286.25(\mathrm{~N}-\mathrm{H}), 1686.13$ (Fmoc-C $=\mathrm{O}), 1644.25$ $(\mathrm{NH}-\mathrm{C}=\mathrm{O}) \mathrm{cm}^{-1} ;$ HRMS $\mathrm{m} / z\left(\mathrm{ESI}^{+}\right)$calc. for $\mathrm{C}_{36} \mathrm{H}_{54} \mathrm{~N}_{2} \mathrm{O}_{4}$ : 578.4083; found $601.3989\left[\mathrm{M}+\mathrm{Na}^{+}\right], 617.3723\left[\mathrm{M}+\mathrm{K}^{+}\right]$.

\subsection{Preparation of the gels}

A given amount of the gelators 1-4 were mixed with $1 \mathrm{~mL}$ of the required solvent in a glass vial with a lid. The mixture was heated slowly until completely dissolved (or sonicated for $1 \mathrm{~min}$ until completely dissolved). Then the solution was cooled to room temperature. After $2 \mathrm{~h}$, gelation was checked visually by inversion of the vial. Gel formation was considered to take place if no flow was observed upon vial inversion. ${ }^{53}$

\subsection{Rheological measurements}

Rheological characterization was carried out using a controlled stress rheometer (MCR 301, Anton Paar, Austria) with parallel plates (15 mm diameter, $0.5 \mathrm{~mm}$ gap) at $25{ }^{\circ} \mathrm{C}\left( \pm 0.1{ }^{\circ} \mathrm{C}\right)$ for samples 3 (toluene) and 4 (toluene) and at $5{ }^{\circ} \mathrm{C}\left( \pm 0.1^{\circ} \mathrm{C}\right)$ for samples 1 (hexane and cyclohexane) and 2 (hexane). Tested gels were placed between the plates and the excess volume of sample was trimmed and the edge was coated with paraffin (Panreac, Barcelona, Spain) to prevent water evaporation during the measurement. A rest time of $15 \mathrm{~min}$ was applied to all samples before measuring.

The linear viscoelastic region (LVER) was determined by means of a strain sweep $(\gamma, 0.01-1 \%)$ at frequency of $1 \mathrm{~Hz}$. The mechanical spectra of gels were obtained by frequency sweep tests from 0.1 to $100 \mathrm{rad} \mathrm{s}^{-1}$ of angular frequency $(\omega)$ at $0.1 \%$ strain (inside the LVER of the samples) to determine the storage, $G^{\prime}(\mathrm{Pa})$, and loss, $G^{\prime \prime}(\mathrm{Pa})$, moduli and the damping factor $\left(\tan \delta=G^{\prime \prime} / G^{\prime}\right)$. All assays were carried out at least in triplicate.

\subsection{Removal of dyes from aqueous solutions by phase- selective gelation}

A solution of RhB or methyl orange in distilled water $(0.03 \mathrm{mM}$, $5 \mathrm{~mL})$ was extracted with a solution of lipoamino acid $\mathbf{1}(0.7 \mathrm{w} /$ $\mathrm{v} \%$ in hexane, $5 \mathrm{~mL})$ or lipoamino acid $3(1.3 \mathrm{w} / \mathrm{v} \%$ in toluene, 5 $\mathrm{mL}$ ). After phase separation takes place, the gels or the organic phase was separated and UV-vis absorption spectra of the aqueous phase were recorded to determine dye concentration after treatment.

\section{Acknowledgements}

We want to thank Maynooth University for the award of the John Hume Postgraduate Scholarship to Jessica Ramos and the Irish Research Council for the award of a Postgraduate Scholarship to Róisín O'Flaherty. We also thank Dr Elisa Fadda (Maynooth University) for molecular modelling of the amino acid core and Dr Wynette Reddington (Materials and Surface Science Institute, University of Limerick, Limerick, Ireland) for performing XPD sample analysis.

\section{Notes and references}

1 A. R. Hirst, B. Escuder, J. F. Miravet and D. K. Smith, Angew. Chem., Int. Ed., 2008, 47, 8002-8018.

2 T. Aida, E. W. Meijer and S. I. Stupp, Science, 2012, 335, 813817.

3 T. Yoshii, S. Onogi, H. Shigemitsu and I. Hamachi, J. Am. Chem. Soc., 2015, 137, 3360-3365.

4 P. Duan, N. Yanai, H. Nagatomi and N. Kimizuka, J. Am. Chem. Soc., 2015, 137, 1887-1894. 
5 B. O. Okesola, S. K. Suravaram, A. Parkin and D. K. Smith, Angew. Chem., Int. Ed., 2015, 55, 183-187.

6 X. Yao, S. Wu, L. Chen, J. Ju, Z. Gu, M. Liu, J. Wang and L. Jiang, Angew. Chem., 2015, 127, 9103-9107.

7 K. J. Skilling, F. Citossi, T. D. Bradshaw, M. Ashford, B. Kellam and M. Marlow, Soft Matter, 2014, 10, 237-256.

8 R. Afrasiabi and H.-B. Kraatz, Chem.-Eur. J., 2015, 21, 1-7.

9 H. Yu, Y. Lü, X. Chen, K. Liu and Y. Fang, Soft Matter, 2014, 10, 9159-9166.

10 X. Yan, F. Wang, B. Zheng and F. Huang, Chem. Soc. Rev., 2012, 41, 6042-6065.

11 C. D. Jones and J. W. Steed, Chem. Soc. Rev., 2016, DOI: 10.1039/c6cs00435k.

12 D. M. Zurcher and A. J. McNeil, J. Org. Chem., 2015, 80, 24732478.

13 S. S. Rohner, J. Ruiz-Olles and D. K. Smith, RSC Adv., 2015, 5, 27190-27196.

14 K. K. Diehn, H. Oh, R. Hashemipour, R. G. Weiss and S. R. Raghavan, Soft Matter, 2014, 10, 2632-2640.

15 J. Bonnet, G. Suissa, M. Raynal and L. Bouteiller, Soft Matter, 2015, 11, 2308-2312.

16 N. Yan, Z. Xu, K. K. Diehn, S. R. Raghavan, Y. Weiss and R. G. Fang, Langmuir, 2013, 29, 793-805.

17 V. J. Nebot, J. Armengol, J. Smets, S. F. Prieto, B. Escuder and J. F. Miravet, Chem.-Eur. J., 2012, 18, 4063-4072.

18 Y. Lan, M. G. Corradini, R. G. Weiss, S. R. Raghavan and M. A. Rogers, Chem. Soc. Rev., 2015, 44, 6035-6058.

19 V. Čaplar, L. Frkanec, N. Š. Vujičić and M. Žinić, Chem.-Eur. J., 2010, 16, 3066-3082.

20 Q. Jin, L. Zhang and M. Liu, Chem.-Eur. J., 2013, 19, 92349241.

21 W. Miao, D. Yang and M. Liu, Chem.-Eur. J., 2015, 21, 75627570 .

22 A. Pal and J. Dey, Langmuir, 2013, 29, 2120-2127.

23 M. Zhang, S. Selvakumar, X. Zhang, M. P. Sibi and R. G. Weiss, Chem.-Eur. J., 2015, 21, 8530-8543.

24 M. Tena-Solsona, B. Escuder, J. F. Miravet, V. Casttelleto, I. W. Hamley and A. Dehsorkhi, Chem. Mater., 2015, 27, 3358-3365.

25 D. Van der Zwaag, P. A. Pieters, P. A. Korevaar, A. J. Markvoort, A. J. H. Spiering, T. F. A. de Greef and E. W. Meijer, J. Am. Chem. Soc., 2015, 137, 12677-12688.

26 C. Tomasini and N. Castellucci, Chem. Soc. Rev., 2013, 42, 156-172.

27 S. S. Babu, V. K. Praveen and A. Ajayaghosh, Chem. Rev., 2014, 114, 1973-2129.

28 S. Fleming and R. V. Ulijn, Chem. Soc. Rev., 2014, 43, 81508177.

29 Y. Xie, X. Wang, R. Huang, W. Qi, Y. Wang, R. Su and Z. He, Langmuir, 2015, 31, 2885-2894.

30 E. R. Draper, K. L. Morris, M. A. Little, J. Raeburn, C. Colquhoun, E. R. Cross, T. O. McDonald, L. C. Serpell and D. J. Adams, CrystEngComm, 2015, 17, 8047-8057.

31 P. Bairi, B. Roy, P. Routh, K. Sen and A. K. Nandi, Soft Matter, 2012, 8, 7436.

32 Z. Xie, A. Zhang, L. Ye and Z.-g. Feng, Soft Matter, 2009, 5, 1474-1482.
33 F. Delbecq, Adv. Colloid Interface Sci., 2014, 209, 98-108.

34 H. Cao, Q. Yuan, X. Zhu, Y. P. Zhao and M. Liu, Langmuir, 2012, 28, 15410-15417.

35 S. Ahmed, J. H. Mondal, N. Behera and D. Das, Langmuir, 2013, 29, 14274-14283.

36 B. O. Okesola and D. K. Smith, Chem. Soc. Rev., 2016, DOI: 10.1039/c6cs00124f.

37 S. Sengupta and R. Mondal, RSC Adv., 2016, 6, 14009-14015.

38 K. K. Kumar, M. Elango, V. Subramanian and T. M. Das, New J. Chem., 2009, 33, 1570-1577.

39 V. S. Sajisha and U. Maitra, RSC Adv., 2014, 4, 43167-43171.

40 J. J. Yan, R. P. Tang, B. Zhang, X.-Q. Zhu, F. Xi, Z. C. Li and E. Q. Chen, Macromolecules, 2009, 42, 8451-8459.

41 M. Bielejewski, J. Kowalczuk, J. Kaszynska, A. Lapinski, R. Luboradzki, O. Demchuk and J. Tritt-Goc, Soft Matter, 2013, 9, 7501-7514.

42 T. Kar, S. K. Mandal and P. K. Das, Chem.-Eur. J., 2011, 17, 14952-14961.

43 X. Chen, P. Fei, K. A. Cavicchi, W. Yang and N. Ayres, Colloid Polym. Sci., 2014, 292, 477-484.

44 Rajkamal, D. Chatterjee, A. Paul, S. Banerjee and S. Yadav, Chem. Commun., 2014, 50, 12131-12134.

45 E. Dahan and P. R. Sundararajan, Langmuir, 2013, 29, 84528458.

46 G. Ghini, L. Lascialfari, C. Vinattieri, S. Cicchi, A. Brandi, D. Berti, F. Betti, P. Baglioni and M. Mannini, Soft Matter, 2009, 5, 1863-1869.

47 L. Lascialfari, G. Pescitelli, A. Brandi, M. Mannini, D. Berti and S. Cicchi, Soft Matter, 2015, 11, 8333-8341.

48 P. Terech and R. G. Weiss, Chem. Rev., 1997, 97, 3133-3159.

49 G. Wang and A. D. Hamilton, Chem.-Eur. J., 2002, 8, 19541961.

50 D. González-Rodríguez and A. P. H. J. Schenning, Chem. Mater., 2011, 23, 310-325.

51 J. W. Steed, Chem. Commun., 2011, 47, 1379-1383.

52 D. K. Smith, in Supramolecular Chemistry: From Molecules to Nanomaterials, ed. J. W. Steed and P. A. Gale, Wiley, 2012, vol. 7, pp. 3355-3376.

53 Y. Liu, Y. Wang, L. Jin, T. Chen and B. Yin, Soft Matter, 2016, 12, 934-945.

54 E. Shapiro, Prog. Polym. Sci., 2011, 36, 1184-1253.

55 K. Fukunaga, M. Yoshida, F. Nakajima, R. Uematsu, M. Hara, S. Inoue, H. Kondo and S. I. Nishimura, Bioorg. Med. Chem. Lett., 2003, 13, 813-815.

56 L. Yang, J. B. Brazier, T. A. Hubbard, D. M. Rogers and S. L. Cockroft, Angew. Chem., Int. Ed., 2016, 55, 912-916.

57 F.-X. Simon, T. T. T. Nguyen, N. Díaz, M. Schmutz, B. Demé, J. Jestin, J. Combet and P. J. Mésini, Soft Matter, 2013, 9, 8483-8493.

58 G. Bastiat and J.-C. Leroux, J. Mater. Chem., 2009, 19, 38673877.

59 S. Fleming, P. W. J. M. Frederix, I. n. Ramos Sasselli, N. T. Hunt, R. V. Ulijn and T. Tuttle, Langmuir, 2013, 29, 9510-9515.

60 V. Serrano, W. Liu and S. Franzen, Biophys. J., 2007, 93, 24292435. 
61 V. A. Mallia, M. George, D. L. Blair and R. G. Weiss, Langmuir, 2009, 25, 8615-8625.

62 S. M. M. Reddy, G. Shanmugam, N. Duraipandy, M. S. Kiran and A. B. Mandal, Soft Matter, 2015, 11, 8126-8140.

63 A. Pal and J. Dey, J. Phys. Chem., 2014, 118, 12112-12120.

64 S. R. Jadhav, P. K. Vemula, R. Kumar, S. R. Raghavan and G. John, Angew. Chem., Int. Ed., 2010, 49, 7695-7698.

65 S. Debnath, A. Shome, S. Dutta and P. K. Das, Chem.-Eur. J., 2008, 14, 6870-6881.
66 X. Zhang, J. Song, W. Ji, N. Xu, N. Gao, X. Zhang and H. J. Yu, J. Mater. Chem. A, 2015, 3, 18953-18962.

67 Y. Zhang, Y. Ma, M. Deng, H. Shang, C. Liang and S. Jiang, Soft Matter, 2015, 11, 5095-5100.

68 S. Bhattacharya, A. Srivastava and A. Pal, Angew. Chem., Int. Ed., 2006, 45, 2934-2937.

69 L. Clary, J. Greiner, C. Santaella and P. Vierling, Tetrahedron Lett., 1995, 36, 539-542. 